\title{
Americanization and Postwar Japanese Management
}

\section{A Bibliographical Approach}

\author{
Takenori SAITŌ \\ Yokohama City University
}

HIS PAPER AIMS at shedding light on the kind of influence the
transfer and infiltration of American management into Japan,
in other words "Americanization," had on Japanese management after World War II. In doing so my basic attitude will be one of trying to concentrate mostly on finding out how Japanese management reacted to this Americanization.

Besides throwing light on how, in concrete, the management of Japanese enterprise felt the impact of Americanization, I would like in this paper to look particularly at the activities of those who provided the intellectual guidance that supported business management in Japan: business management scholars and management consultants. Besides being directly involved in the improvement of Japanese management, those scholars and consultants who were influenced by Americanization also published numerous books and articles to support their positions. I also propose in this paper, therefore, to introduce readers to the fruits of their studies: their writings. 
This study of the influence of Americanization on Japan's management will be limited to the period of approximately twenty years from the end of the war, or about 1965. But before entering into this discussion it is necessary, it seems to me, to say something about the Americanization that took place before the war, as well, and so I would like to begin with a summary of this prewar period in the next section. ${ }^{1}$

\section{AMERICANIZATION IN JAPANESE MANAGEMENT PRIOR TO WORLD WAR II}

Following the Meiji Restoration of 1868, the Japanese government of the time promoted industrialization. In order for Japan to catch up with the advanced industrialized countries of Europe and the Americas, the government adopted the enterprise system and had specialists learn not only the advanced technologies used in European and American enterprise but also their business management. If we confine our attention only to the makers of electrical machinery and appliances, for example, we see numerous mergers or tieups formed between Japanese and overseas companies: NEC with Western Electric, Toshiba with General Electric, Fuji Electric with Siemens, and Mitsubishi Electric with Westinghouse. Through these alliances Japanese enterprise effected the transfer into Japan of technology and management practices developed by Western enterprise.

Let us take Mitsubishi Electric as a case in point. In 1923 it entered into a tieup arrangement with Westinghouse. In addition to introducing technology related to electrical machinery and appliances learned from Westinghouse, it would also accept know-how and techniques related to management, such as plant management and marketing,

${ }^{1}$ The following works were used by the author in the research for this paper and were helpful in its production: Takenori Saitō, "Nihon Keieigaku no keifu" [Business administration in Japan: A genealogy], in Hidetoshi Suzuki, ed., Keiei gakusetsu [Theories of business administration], Dōbunkan, 1976; Saitō, Keiei kanni ron no kiso [Basics of business management theory], Dōbunkan, 1983 (the supplement to chap. 1, pp. 48-58); Saitō, "Keieisha kyōiku" [Education of managers], in Shin'ichi Yonekawa, ed., Keiei shi [History of management], Dōbunkan, 1986; Saitō, "Nihon ni okeru keieigaku" [Business administration in Japan], in Hidetoshi Suzuki, ed., Keieigaku sōron [Introduction to business administration], 2nd ed., Seibundō, 1989; Takashi Namiki et al., Monozukuri o ichiryū ni shita otokotachi-Nihonteki keiei kanri no ayumi o tadoru [Men who made making things first-rate: Tracing the path of Japanese-style management], Nikkan Kōgyō Shinbunsha, 1993. 
and put these into practice. The result was that the company's management was once described in these words:

The Japanese methods of business management were transformed into scientific management. In other words, management methods that were systematic, that were calculated, that assessed everything in money terms.... When a new product was developed, we would make estimates of the range of its uses and of the quantity to be made and draw up a budget before we made a final decision on production. While these and similar practices are now considered obvious, in those days they forced us to make a major shift in our way of thinking. ${ }^{2}$

For approximately ten years after the tieup with Westinghouse, Mitsubishi Electric strove to transfer to the company, and penetrate it, with contemporary American management practices, of which F. W. Taylor's "scientific management" was the most representative. Two Americans who visited Japan at the time, H. Emerson, leader of the "industrial efficiency" movement who enjoyed as wide a repute as Taylor, and H. K. Hathaway, a disciple of Taylor, were engaged by the company to provide direct training to the company's workers.

Thus Japanese management of the latter half of the 1920 s can truly be described as under the influence of Americanization. Besides the visits of Emerson and Hathaway there was a visit by another Taylor disciple, C. Barth, in 1924; then there were visits in 1928 by C. Bedaux, known for his work on salary payment methods, A. Thomas, secretary-general of the International Labor Office, and E. Filene, head of ILO's diplomatic section; through all such visits the aim was to make people aware of, and to introduce, scientific management. ${ }^{3}$

${ }^{2}$ Mitsubishi Electric, ed., Kengyō kaiko [Our founding: Recollections], 1951, p. 72.

${ }^{3}$ For more information on these matters, please consult the following of my works: Ueno Yöichi-hito to gyōseki [Yōichi Ueno: The man and his achievements], Sannō Institute of Business Administration, 1983; Ueno Yöichi to keieigaku no paionia [Yoichi Ueno and pioneers in business administration], Sannö Institute of Business Administration, 1987 (this work throws light on the exchanges between Ueno and other scientific management proponents, particularly American, and gives some idea of the Americanization taking place at the time); "Ueno Yöichi to kagakuteki kanri no kokusaika" [Yōichi Ueno and the internationalization of scientific management], in Shögaku ron$s h \bar{u}$ (Fukushima University), vol. 57 no. 2, 1989; "Kagakuteki kanri no kokusaika to teirā shugisha no kōryū" [The internationalization of scientific management and exchanges among Taylor followers], in Terushi Hara, ed., Kagakuteki kanri hō no dōnyū to tenkai- 
Two events show most symbolically the Americanization that took place in Japan before the war. ${ }^{4}$ The first was the World Engineering Congress held in Tokyo in the autumn of 1929. One section of this congress, which was an international conference at which were gathered engineers from all over the world, was devoted to the topic "scientific management," and from the United States were sent J. R. Freeman, president of the American Society of Mechanical Engineers, to represent the Taylor Society; W. Lewis, a man who understood Taylor's ideas and who was the president of Tabor Company, which had become a model factory for implementing scientific management; and the psychologist Lillian M. Gilbreth, the wife of F. B. Gilbreth.

It must be remembered, though, that besides business management experts from the United States, representative business management experts from Europe also visited Japan; these were people who, in the midst of the impact scientific management was making on the countries of Europe, were involved in similar movements. Among these visitors were people like F. Mauro, president of the recently founded International Management Institute and professor at the Engineering College of Milan, and G. Schleshinger, foremost proponent of Germany's rationalization movement. The result was that, at the aforementioned World Engineering Congress in Tokyo, heated discussions took place over the question of the influence of scientific management on workers, particularly in regard to the relationship between scientific management and unemployment.

One other point. The two Japanese who were virtually the moving forces behind the congress were Töichirō Araki, a management consultant who had returned from the United States, and Yöichi Ueno, founder of the Sannō Institute of Business Administration. These two were pioneering management consultants in Japan. Their contributions raised the introduction of scientific management from the bibliographical research level of translations of American scientific-management-related works and introductory works on the subject-the level maintained from the years 1912 to 1926 - to the practical level

somo rekishiteki kokusai hikaku [The introduction and development of scientific management: A historical international comparison], Shōwadō, 1990 (this work is mainly concerned with exchanges that took place between America and Europe).

${ }^{4}$ For more on these two events, please see the two books of mine given in note 3 . 
of actually applying scientific management to Japan's industrial circles and enterprise. To put it another way, Japanese management at the time already considered (as can be seen in the case of Mitsubishi Electric) scientific management practices as a necessity.

The second event that was symbolic of Americanization was the sending in 1930 of an American factory observation team; this team was organized and sent by the Japanese branch of the Taylor Society, at the invitation of the Taylor Society head office in the United States. Now this society had been founded in 1915, after Taylor's death, for the purpose of spreading scientific management within the United States and Europe, and then globally. And ten years after its founding, lo and behold, the first overseas branch to be founded was here in Japan, with the Yōichi Ueno mentioned above the main driving force.

Anyway, Ueno and a dozen or so managers of Japanese enterprises toured American enterprises for about two months, learning what they could. At the time the United States was in the grip of the Depression, but the observation team was welcomed by Taylor Society members and enterprises wherever it went. The team returned to Japan with deep and lasting impressions of the differences between American management applying scientific management and the paternalistic Japanese management practices.

Still, even though Americanization made progress in industrial circles and had an influence on Japanese management, most of the teachers engaged in higher education for those going into business were not to be affected by Americanization. Rather, they leaned toward, and were reliant upon, the business administration that had developed in the German-speaking world: Betriebswirtschaftslehre, or an economics of enterprise that did not take the engineering approach that scientific management did.

Furthermore, in the midst of the impact on contemporary Japanese social sciences made by Marxism, there was generated a Marxist theory of business administration, which made a show of criticizing the problems that attended the enterprise management of capitalist countries. A book by Torao Nakanishi, professor at Tokyo University, entitled Keiei keizaigaku [Betriebswirtschaftslehre], published in 1931, was a pioneering effort. The result of the birth of this Marxist management theory was that there would arise between the industrial 
circles and academic circles in Japan an enduring confrontational tension. ${ }^{5}$

Thus scientific management, with its symbol of the American management of that age (its practical orientation), was not accepted in Japanese academic circles; on the contrary, it was an object of rejection and scorn. After the Taylor Society and the Society of Industrial Engineers merged, Yōichi Ueno in 1935 renamed the Japanese branch of the Taylor Society that he had been instrumental in founding, now calling it "Amerika Keiei Gakkai Nihon Shibu" [Japan branch of the Society of American Business Administration]. Its membership, however, was limited to a very few people, mainly experts in factory management. ${ }^{\text {i }}$

In the wake of the later worsening of U.S.Japan relations and the subsequent rupture of all relations, Americanization in the industrial world also retrogressed. In its place there appeared a surge in morale and efficiency stemming from a heightened "Japanese spirit" (Yamato-damashii), and more value was place on idealism than on the scientific or rational qualities found in American business management. As examples of works that glorified such idealism we can mention Sadao Hatano's Kōjō keiei kanri [Shop management], published in 1940, and Sangyō nōritsu to seishin shidō [Industrial efficiency and moral training], edited by Nippon Keizai Renmeikai and published in 1943.

The war demanded a production management that would be able to supply with efficiency the materials needed for the prosecution of that war. Instead, with the start of the war Japan abandoned Americanization, and preference was given to a production management based on a glorified Japanese spirit. The eventual upshot was Japan's defeat in the war.

\section{AMERICANIZATION AFTER WORLD WAR II}

Americanization, which had come to an end as soon as the war

\footnotetext{
${ }^{5}$ Nakanishi would later, after the end of the war, distance himself from this position, and he turned his interests to research on cost accounting and administrative finance.

${ }^{6}$ Academic lecturers had, in 1926, founded the Nihon Keiei Gakkai [Japan Society of Business Administration].
} 
between Japan and the United States began, would commence once more as soon as Japan surrendered in August of 1945. The framework of the wartime regime that had dominated Japanese society till then was dismantled by the Occupation Forces, and at the same time steps were taken to democratize Japanese society. In the economic and business worlds, too, the democratization of enterprise management and production systems was pushed forward, with a key move being the dissolution of the zaibatsu.

Postwar Japanese management was forced to tread the path of rebirth and reconstruction under the influence of free democratic ideology. And it became imperative that worsening confrontational labormanagement relations be changed into cooperative relations. In the midst of these conditions the ideas of A. A. Berle and G. C. Means, who had published his The Modern Corporation and Private Property in 1932, on the separation between ownership and management and on controlling managers, and of J. Burnham, who had published his Managerial Revolution in 1941, were introduced to the Japanese business world, and opinions concerning a democratization of enterprise based on a revised capitalism, advocacy of more harmony between labor and management (with the catchphrase that "all who work in an enterprise are managers"), and the theory of professional managers were all being put forward not only by academics but also by progressive groups of managers.

In this fashion a foundation was laid during the years 1945-1954 for the introduction of American management. To be specific, first of all let me mention the education aimed at factory-floor managers through such practices as TWI (training within industry), which had been systematized during World War II to the extent that manuals were produced on the subject, or the holding of quality control seminars.

Along these same lines the work of M. C. Niles, Middle Management (1949), and similar works were translated into Japanese as an aid to further research and education directed toward middle management and under in Japan. And let us not forget that already before World War II there had been a considerable amount of knowledge and techniques related to factory-level scientific management, production control, and industrial engineering introduced into and stored up in Japanese enterprise. 
Another specific measure that can be mentioned is the introduction of research on top-level management. Whereas prewar Japan's academic circles were controlled by the managerial economics, or Betriebswirtschaftslehre, of its ally in the war, Germany, the defeat of both countries in the war naturally led to a waning of the influence of the German approach and a corresponding growth in the influence of the American approach. American business administration, whose point of departure was scientific management on the factory level (as represented by the $\mathrm{F}$. Taylor model), would go on to develop from the 1940 s and into the late 1950s, and as it did it would also generate research with an executive perspective. There were, it is believed, three reasons for the development of research with top-management concerns.

First of all, the research on, and education in, business management that had started out in the United States from scientific investigation of the production sector gradually spread, from the 1920 s on, to other functional sectors in an enterprise, so that it led to personnel management, office management, marketing management, and the like, and at the same time, seen in terms of the different strata within an enterprise, it progressed from the lower strata to the highest, eventually focussing upon top management.

Secondly, the Great Depression brought about a heightened sense of distrust and insecurity in regard to large enterprises and top management. Against the background of such a general mood, teachers in charge of higher business education and researchers specializing in business administration were constrained by the need to provide truthful answers to the questions: What are the objectives of enterprise? What roles ought to be fulfilled by the key players in enterprises: the top management? The Functions of Executives (1938), by C. I. Barnard, was one of the outstanding fruits of such efforts to provide answers to those questions.

Thirdly, with the end of the war the circumstances surrounding enterprises underwent such sharp changes, as compared with the prewar environment, that the reactions of top management to such environmental changes came to be an important topic of research. In these circumstances it was natural that academic interest in top management would heighten.

The result of the rise in management research with a focus on the executive level was its inevitable introduction into Japan. Works like 
P. E. Holden's Top Management Organization and Control (1951), E. Dale's Planning and Developing the Company Organization Structure (1952), and Standard Oil's Management Guide (1948) were translated, and energetic efforts were put into introducing and applying American business administration into our nation's enterprises.

The teachers involved in higher business education who had leaned toward the German model before the war would, even as they remained conscious of prewar research methods and findings, in large numbers concentrate their research on American management. Leadership in this regard was taken by Eiichi Furukawa, Shigetaka Mōri, and Akira Yamashiro, staff at Hitotsubashi University, one of the key institutions involved in higher business education in Japan. It was in this period that these men published large numbers of representative works: Furukawa, with his Amerika keieigaku [American business administration] in 1949 and his Keiei kanri [Management] in 1951, among other works; Mōri, with his Keiei kanri söron [Introduction to management control] in 1948, and Yamashiro, with, for example, his Keiei seisaku [Business policy], in 1957.

Others were active as well. In 1954 Yasujirō Yamamoto, who had made an enormous contribution through a survey study of business administration's development and its characteristics, published his Keiei kanriron [On management]. In the same year there appeared the Keieigaku to ningen soshiki no mondai [Business administration and the problem of human organization], by Keiji Baba, professor of Tokyo University. ${ }^{7} \mathrm{~A}$ work that situated organization theory at the very heart of business administration, Baba's book was a pioneering achievement that provided a thorough introduction to Japan of human relations theory, which was the leading doctrine to appear after Taylor's scientific management theory, and the theory of C. I. Barnard and H. A. Simon.

${ }^{7}$ The 1984 second edition of The Golden Book of Management (edited by L. Urwich, eminent British business scholar, and a team of other scholars and originally published in 1956), mentions 108 pioneers in business research from around the world. The list includes 53 Americans, 15 British, 9 French, and 8 German researchers. Seven Japanese make the list. Besides three who have not been mentioned in this paper (Teijirō Ueda, Fukumatsu Muramoto, Yasutarō Hirai, and so on), the book mentions Torao Nakanishi, Yöichi Ueno, and Keiji Baba. Except for Ueno, all were leading teachers involved in higher business education. 
Within the history of the development of business administration, scientific management has been termed "classical theory," the human relations theory "neo-classical theory," and the BarnardSimon theory "modern theory." Baba was quick to note the new research trends of the neo-classical and modern theories, which made use of behavioral science and interdisciplinary methods, and quick also in assessing them highly.

Still, a little more time would be needed for the Barnard-Simon theory to be accepted. In 1966 Kuniyoshi Urabe, professor at Kobe University, an institution that had supported the development of higher business education in Japan along with Hitotsubashi University, published a book entitled Kindai kanrigaku no tenkai [The development of modern administrative science]. It was through this book that the Barnard-Simon theory would gain a solid foothold in Japan's academia.

It also took time for academics to get accustomed to the idea of "Management is process" and to the approach of trying to explain the functions and activities of managers in terms of the framework of management process. This viewpoint had been developed by $\mathrm{H}$. Fayol, a French mining executive who was a contemporary of Taylor, and it had an especially strong impact on business administration research in the United States after World War II.

Principles of Management (1955), by H. Koontz and C. J. O'Donnell, is a textbook that well represents that viewpoint, and it has been read in translation by large numbers of business students and businessmen in our country. Nevertheless, we had to wait until about the middle of 1960 for works by Japanese researchers that thoroughly reflected that viewpoint: Gendai keieigaku nyūmon [Modern business administration: An introduction], by Nobuyuki Sakurai, professor of Aoyama Gakuin University; Keieigaku genri [Principles of business administration], by Akira Yamashiro; and Manejimento purosesu [Management process], by Misao Sekiguchi, professor of Keiō University.

Besides the TWI and other educative measures aimed at factorylevel managers, and the introduction of research on top-level management, there were other aspects to the advance of Americanization in Japan in the ten years after the war. For example, the development of automation technology and office management technology in the United States were things that naturally had an impact on both enter- 
prise and the academic world in Japan. And the Japanese academic world would also receive the influence of management science, including such things as managerial economics, pioneered by $\mathrm{J}$. Dean, and operations research.

Furthermore, the influence of individual people, people like P. Drucker, must also be noted. I have already said something about the influence of Berle, Means, and Burnham. Their place was to be taken by Drucker, whose point of departure had been a critique of Western civilization, and who was the author of numerous works, such as The Practice of Management (1954). Almost all of his works were translated into Japanese, and they were to produce large numbers of scholars and students who, attracted by his theories, would do further research on his writings. At the same time his ideas and insights about enterprise and managers enlightened many executives and businessmen. What is more, even ordinary citizens who had little to do with business were familiar with his name because of his many visits to Japan. Later the Japanese government would, in appreciation of his achievements, bestow on him the Third Order of Merit.

There were other individuals who influenced the course of business management in Japan, as well. Thus, for example, we have W. E. Deming, whose name was well known because of the Deming Prize (established in 1951) given to commend enterprises that had made outstanding efforts in quality control. Deming made an enormous contribution to the quality control movement in Japan; he played a major role in fostering an important feature built up by Japanese management after the war: the idea that "the products of Japanese enterprise are of good quality and still inexpensive." Finally, representative of a number of American economists who made a huge impact on Japan's industrial world and its businessmen, was J. K. Galbraith.

Despite the influence of these other individuals, however, the impact of Drucker's many works, so rich in ideas, is thought to have overshadowed that of all the others. The thoughts and the insightfulness of the man in regard to enterprise and managers, made public in a steady stream of publications and exemplified by ideas on changes in industrial society, enterprise goals (the creation of a clientele, necessary minimum profit, etc.), "creativity" and "innovation" as the roles of managers, and similar ideas, constantly gave fresh stimuli to Japanese enterprise. 
Thus, it would not be appropriate to speak of "exclusive leaning towards America"; rather, it was more a case of "learning from America." Anyway, for ten years after the war Americanization would advance and spread in both the practical arenas and research arenas of Japanese enterprise. Keeping pace with movements in those arenas, the Japanese economy would make a sure and steady recovery, to become a sound foundation able to support the amazing "high economic growth" that was to come later. Postwar Japan would one day be called an economic power as a result of the high rate of growth of this economy. Another thing: the Americanization that took place during these ten years would give rise to what is termed a "business administration boom." A book produced by Fujiyoshi Sakamoto, who had been earning a living by management consultant activities in JapanKeieigaku nyūmon [Introduction to business administration] (1959)was a small, instructive work that explained in simple language the way business administration was conceived and what American business administration was all about. Yet it enjoyed an explosive popularity and announced the beginning of a business administration boom.

As I have already mentioned, Japanese management in the second half of the 1920s was under the influence of Americanization. If we consider that period to be the first business administration boom, we can consider this ten-year period after the war the second business administration boom. This latter was a boom on a huge scale, such that the first one was almost nothing in comparison. The high economic growth of our country, which would become the object of worldwide amazement, would become possible as a result of many different factors, but this business administration boom resulting from Americanization can surely be considered one of those factors.

\section{LATER DEVELOPMENTS AND SOME ASSESSMENTS}

What does it mean to say that a business administration boom that resulted from Americanization was one of the factors that made Japan's high economic growth after the war possible?

While pushing for the democratization of society in the ten years after the war, the people of Japan were striving to revive and revitalize an economy that had been turned to ashes by war, and they were 
successful in their efforts. During this period, as I have tried to show in the preceding section, Americanization was making advances within Japanese management.

Now, the introduction and adaptation of American management during this period were passing through almost the same phases as when Japan adopted American management based on scientific management before the war: while university instructors were focussing their activities on the introduction and translation of American business management ideas and publications, the practical people, the executives and consultants who were immediately involved in running enterprises, were trying, with a sort of belief in American management and without taking fully into account the different set of circumstances in Japanese enterprise, to adopt and put to immediate use those ideas in the arena of actual practice. And the stronger the belief of these practical people in American management, the more convinced they were that the rational, highly productive American way of management was an excellent model of business management, the more sure they felt they could apply those ways at once in the practical arena. And this sort of belief, it seems clear, was a controlling force over a considerable number of scholars and practical people even in the decade that followed the first decade after the war.

Thus, for example, such large multinational enterprises as IBM and Coca Cola, which had entered Japan after the war, were symbols of the superior business management of American enterprise, while the Big Three in the American automobile industry were looked upon as targets for Japanese enterprises to catch up with. These American enterprises were, in other words, the ideal management models to be emulated by Japanese management. This was true also of European enterprises, but as far as enterprise management went, America was Japan's model, its paragon, its exemplar, its teacher.

At any rate, the general image of the introduction and adaptation of American business management in the ten years after the war is almost one of something being swallowed whole, of "direct importation." And during these ten years Japan would achieve an economic revival and go on to face a new stage. To be specific, Japan would go on from achieving revival to move in the direction of a new advance, in the form of the "productivity improvement movement." 
When the Japan Productivity Center in 1955 was established as a private group representing the executives that formed its core, ${ }^{8}$ Japan would announce the opening of curtains on a new stage in its history: the period of high economic growth. The second business administration boom represented the flowering of this movement. The productivity improvement movement, which would evolve with industrial circles forming the core of the movement and which would even be symbolized by the book by Fujiyoshi Sakamoto, still could not escape the image of a "direct importation" of American management, but at the same time it fulfilled the role of enabling American management to spread beyond the confines of the industrial world, to penetrate, and take a deep hold in, the wider Japanese society. To put it another way, through this movement American management was given the opportunity to be popularized, to be diffused widely into Japanese society.

This phenomenon of the popularization of American business management in our country would lead to the large-scale development of business management education and reveal it in its concrete form. Even though higher education for people going on into business had developed both quantitatively and qualitatively more or less around the time of the first business administration boom in Japan, during this period it would show an equal development. The high economic growth in secondary industry and the manufacturing industry was heavily dependent upon technology and technological reform, and this gave a positive stimulus to the development and expansion of education in faculties of engineering.

In step with university-level engineering education, however, there was a rapid development in business management education on the university level. Higher business education in the first business administration boom, though it did include the production control that was built around Taylor's scientific management, mainly consisted of things like the study of merchandise, marketing, business practice for international trade, accounting, and the German management economics (Betriebswirtschaftslehre) that was then in its formative stage. The origin of higher business education in Japan goes back to

\footnotetext{
${ }^{8}$ The spiritual backbone of the Japan Productivity Center was Kōhei Gōshi. His work, Bunmei no katasumi kara [From a corner of culture] (Tōkyō Shobō, 1960), is invaluable for anyone wishing to learn his thinking at this time.
} 
the establishment of the Handelshochschule in Tokyo in 1888 (it later became the present-day Hitotsubashi University); while it made steady progress after its founding, its purpose was to train international businessmen who would be able to handle international transactions. Then, when the period of the first business administration boom came around, an additional purpose was envisaged, that of nourishing personnel that could conduct the management of enterprise.

In contrast, the business management education that evolved with great energy under the second business administration boom had as its purpose, under the influence of American business administration, the training of personnel familiar with enterprise management. Thus, while schools of commerce were most common up until the first business administration boom, when the second boom occurred large numbers of schools of business administration were established, mostly in private universities. The first such schools were to be located at Kobe University in 1949 and at Meiji University in 1953, but the majority of them were founded around the year 1965 .

Likewise, in faculties of economics in national universities and private universities-and in Japan there are many universities with such faculties-departments of business administration were added on before long, while in engineering faculties departments of industrial engineering (or management science) were added on.

The year 1965 also formed a threshold of sorts, because it was around that year that the ratio of high-school students going on to university studies suddenly increased and crossed over the "university-for-theelite stage" of less than 10 to 15 percent of the student population of the same age to plunge suddenly into a "university-for-the-masses stage." In the midst of such a change the position of business management education, especially, took on greater meaning, and many young students began studying business management. In this way business management education in the universities took on the air of "big business," in that it had a huge clientele.

Still, even though business management education on the university level made great strides, the main emphasis was on undergraduate education. This was very different from the situation in the United States, where after the war postgraduate education in a professional school was given more weight and, as can be gathered from the common saying, "the acquisition of an MBA is a shortcut to joining the 
business elite," the goal was the training of specialist managers and management consultants.

In the case of Japan, where importance was given to undergraduate education, it was possible to foster personnel that were well versed in enterprise management, but it was not possible to foster personnel that could successfully implement enterprise management. And there was no need, as far as Japanese enterprise was concerned, to seek to foster in university management education personnel with practical abilities, since each company provided its new recruits with practical management education. ${ }^{9}$

In this way business management education would, under the influence of American management, develop on a large scale not only within enterprise but also in the university classroom. In the second decade after the war, which opened with the unveiling of the productivity improvement movement, the writings of many individuals, first and foremost of Drucker and Barnard, would be translated. (This set a trend that has not ended; even today many of the works on management published in the industrially advanced countries of the world are being translated and published in Japan.)

During this period the Japan Productivity Center would send to the United States numerous executives and specialists from different enterprises in order to learn American management at first hand. This was merely a repetition of similar moves attempted by Yōichi Ueno 25 years earlier, but on a much grander scale.

Meanwhile there would continue to be introduced into Japanese enterprise such American practices as: case method as a method of business management education; (long-range) business planning and business strategy to bring out into the open an enterprise's objectives; the new organizational forms of operational divisions and projects; value analysis; value engineering; personnel management based on the application of behavioral science, the "new human relations theory"; mass marketing and mass distribution systems following in the wake of the solid entrenchment of mass production systems; and the supermarket method. Even afterwards Japan responded

\footnotetext{
${ }^{9}$ This is why Japanese companies rarely placed those of its employees whom they sent overseas to obtain an MBA at some professional school in Europe or the United States into positions or tasks that were suitable to their qualifications upon their return to Japan.
} 
actively to management know-how and techniques developed in the United States. This all was in remarkable contrast with the fact that at the same time the products of Japanese enterprise were penetrating widely into American and other overseas markets and making a name for themselves.

Now, even as Japanese enterprise was making possible and supporting its high economic growth through the introduction and adaptation of American management, it would slowly and steadily accumulate and strengthen its management skills until it bore fruit in the superiority and power of Japanese management. In other words, Japanese enterprise would take on management skills and transform itself from the feeble creature it was at war's end.

In the early 1980s, after the publication of G. W. Ouchi's Theory $Z$ (1981) and R. T. Pascale and A. G. Athos's The Art of Japanese Management (1981), Japanese management came to be appreciated and noted as one of the outstanding models of management by the United States and other industrially advanced countries. This newfound respect seems to have been engendered when attention was turned to Japanese management after it successfully steered Japanese enterprise through the tough changes in the business environment that occurred after the two oil shocks of the 1970s. At any rate, the upshot was that Japanese management became a model of business management and there sprang up among overseas countries the "learn from Japan" fad.

Still, if we think that, even if we give full credit to the role of Americanization in Japanese management's rise even to the point of becoming a model, there are nonetheless special characteristics in Japanese management that are different from American management and that Japanese enterprise developed on its own, it has to be said that there were limits to the extent to which Americanization had an impact.

When the economic slump that followed the 1964 Tokyo Olympics had reached serious depths, there suddenly erupted in industrial circles in Japan a loss of faith in American management, which had been introduced and adapted with such enthusiasm. Thus, for example, the special theme of the October 1965 issue of the monthly magazine Bijinesu [Business] was "Business Administration: A Fallen Idol?" And the special theme of the November issue of Keizai semina 
[Economics seminar] in the same year was "Have we seen the collapse of business administration?"

As a result, much reflection is now going on in regard to some basic questions: Was American management actually transferred to, and did it really become functional in, Japanese enterprise? What is really meant by "Japanese management"? In what ways was it influenced by American management? Was the attitude toward the introduction and adaptation of American management a desirable thing?

Seen from today's perspective, Japanese management in its status as a model of management can be seen as composed of a mix of parts that have been created by enterprises in Japan on their own and parts that have been influenced by Americanization. Obviously the "learn from Japan" fashion that began in the early 1980s laid greater stress on the parts that Japanese enterprises developed on their own. I believe that now is the time when the latter parts ought to be fairly assessed once more and given their proper place in the scheme of things. 